\title{
READING COMPREHENSION SKILLS OF STANDARD 4 PUPILS: A COMPARISON OF PRIVATE AND PUBLIC SCHOOLS IN BOTSWANA
}

\author{
Rose Letsholo-Tafila \& Modupe M Alimi \\ University of Botswana
}

This paper compares the reading comprehension of standard $4^{1}$ pupils in four primary schools, two public and two private schools in urban and rural settings in Botswana. Using a standard comprehension test administered to the pupils, the study answers two main questions: Are there significant differences between the comprehension abilities of (a) public and private school pupils, (b) rural and urban private school pupils, and (c) urban and rural public school pupils? What are the implications of the differential abilities for the pupils' academic success? The findings show that the private school pupils performed better and that the urban private school pupils were better at extracting information and making inferences, while the rural private school pupils were better at interpreting information. The study underscores three areas of need: enhancing learning environment in public schools, building a strong foundation for critical/analytical reasoning and maintaining reasonable class size.

Keywords: reading comprehension, inferential skills, public schools, private schools, motivation

\section{INTRODUCTION}

In Botswana, the results of the primary school leaving, junior secondary school and senior secondary school examinations are reported each year to be worse than those of the previous year, particularly in public schools. While the media expresses a great deal of frustration each time these results are released, there has been no formal investigation into the reasons why the results get worse, nor has there been a concerted effort to examine the difference in the performance of students in private and public schools. It is this latter untapped area that this study explores. Our goal in this study, which is part of a much larger study that focuses on the reading achievement of pupils, was to compare the reading comprehension abilities of standard 4 pupils in four primary schools, namely two Tswana medium ${ }^{2}$ public schools, one in the city and the other in a rural setting, and two English medium schools, one in the city and one in a rural setting. We chose to investigate the English reading comprehension level of standard 4 pupils largely because it is an important transition point in children's development as readers (Mullis et al., 2011). The literature indicates that, typically, students have learned how to read at this point and are now reading to learn (Mullis et al., 2011). Thus, the objective of our study was to compare the reading comprehension abilities of standard 4 pupils in the selected four schools to see whether they differed significantly. Our research questions were: Are there significant differences between the comprehension abilities of (a) pupils in private and public schools, (b) pupils in rural private and urban private schools, and (c) pupils in urban and rural public schools? What implications, if any, do the differential abilities have for the academic success of the pupils? 


\section{THEORETICAL FRAMEWORK}

\section{Constructivism}

The analysis in this paper is informed by the theory of constructivism, which posits that individuals actively construct knowledge (Woolfolk \& Margetts, 2013), and learning is the outcome of the active involvement of the learners as they integrate new and existing knowledge. In addition, the theory perceives learning as an internal process that is not necessarily observable externally, but that results from an individual's hypothesis-testing through the process of making inferences.

Constructivism has a number of sub-theories, including inquiry learning, schema theory, transactional/reader response theory and psycholinguistic theory. Some aspects of each of these sub-theories are relevant to the subject under discussion in this paper. Inquiry learning was developed by Dewey $(1910,1916,1938)$, who emphasised that both the environment and the teacher have a significant role to play in the development of the learner, who is considered to be actively involved in the construction of knowledge. In other words, the learner formulates hypotheses, collects data to test the hypotheses, and draws conclusions from the data. Schema theory holds that people organise the knowledge they have into schemas or knowledge structures. Schema theory therefore purports to explain how learners create knowledge as well as how they use this knowledge. With specific reference to reading, schema theory predicts that, without adequate existing schemas on the topic of a text, the skills needed to read the text and the structure of the text, reading comprehension will not be successful (Tracey \& Morrow, 2006). Transactional/reader response theory posits that every individual has a unique reading experience because each reader has a unique background schema. In addition, the transactional/reader response theory holds that each individual has two responses to texts: efferent responses, which are based on facts, and aesthetic responses, which are based on emotions. Psycholinguistic theory begins with the premise that reading is a language process, and as such, readers rely on syntactic, semantic and graphophonic cues to help them process a text. Our investigation of reading comprehension in this study was guided by the notion that learners are active participants in the learning process who make a conscious effort to integrate previous knowledge with the new, using available syntactic, semantic and phonological language resources as cues in their reading encounters.

\section{Reading comprehension: definitions and components}

Reading comprehension comprises cognitive operations which readers employ when constructing meaning in transactions with texts (Block et al., 2002; Dechant, 1981; Keenan et al., 2008; Keene \& Zimmerman, 1997; Pearson \& Fielding, 1991; Pressley, 2000). Hoover and Gough (1990) define reading comprehension as a combination of decoding and oral comprehension skills. This definition assumes that, if a reader can convert what he or she reads into some meaning, then he or she necessarily understands the text. More recent definitions of reading comprehension, however, offer new perspectives which indicate that definitions which focus only on the cognitive are deficient, since reading comprehension is an interplay of not just cognitive factors but also of social and cultural factors. Snow (2002), Hammerberg (2004) and Serafini (2012), for example, assert that the construction of meaning is an interactive process involving more than just decoding the words. All three authors note that readers come to the act of reading with their prior cultural, linguistic, literary and life experiences, which play a crucial role in the process of reading. In this paper, we adopt the perspectives of reading comprehension explicated in Snow (2002), Serafini (2012) and 
Uccelli et al. (2015), who consider reading comprehension as the interplay of both cognitive and sociocultural factors. In the context of this paper, we define reading comprehension from the constructivist approach as the process through which the pupils interact with text in a dynamic way in order to construct meaning from it using their background knowledge, the information inferred from the written language and the reading situation itself.

August et al. (2006: 222) indicate that success in reading is determined by the presence of some interrelated skills, including 'decoding skills (reading words accurately and fluently, accessing lexical representations) and knowledge in several domains (vocabulary, linguistic structure, and discourse as well as world knowledge)' (see also Snow \& Matthews, 2016; Kieffer \& Lesaux, 2007, 2010; Taylor et al., 2011). In addition to these two skills, August et al. (2002: 222) consider 'cognitive processing capacities (memory for text, accessing relevant background knowledge, drawing justified inferences)' equally important. This implies that reading comprehension is only successful to the extent that these three domains of knowledge and processes provide the necessary input in the reading endeavour. Another important inference that can be made from this claim is that any test that will assess reading comprehension fairly accurately should target or aim at determining how learners perform in these domains. Similarly, developing strategies to improve learners' reading comprehension must take cognisance of these domains. In our comparison of the comprehension skills of the learners in the study, our main focus was on the third domain of cognitive processing capacities. We were particularly keen on assessing the learners' memory for text through their recapitulation of basic information from a text, their ability to access relevant background knowledge by extracting information from a text, and their ability to draw justified inferences from it.

Motivation is cited as a factor that impacts academic performance (see Dornyei, 2001). The connection between lack of motivation and academic self-concept is particularly interesting. Chapman et al. (2002: 703) also note that 'achievement related self-perceptions influence achievement through their effect on motivation' (see also Borkowski et al., 1990; Schunk, 1991). Henk and Melnick (1992: 111) rightly claim that motivation or the lack thereof, which arises from how a learner perceives him- or herself academically, could influence whether or not 'opportunities to read would be sought or avoided, the amount of effort that would be expended during reading, and the degree of persistence in pursuing text comprehension', a perspective shared by more recent studies, including those of Sukor et al. (2017) and OrhanÖzen (2017). Even though the relationship between achievement and academic self-concept seems to vary with age, Chapman et al. (2002: 703) note that 'achievement related selfperceptions form and develop in response to early learning experiences'. Citing Chapman and Tunmer (1997), Helmke and Van Aken (1995), and Skaalvik and Hagtvet (1990), Chapman et al. (2002: 703) affirm that 'academic self-perceptions form in response to how well children master important academic skills, their experiences of ease or difficulty with academic tasks, and the manner in which academic performance is interpreted by teachers.' Thus, reading comprehension is not only a component of learning activities, but is also an important index of academic success.

\section{STUDIES ON READING COMPREHENSION}

One study focusing on reading comprehension in Botswana is Arua and Lederer's (2003) study, which examined whether or not high school students enjoy reading and the factors that promote the development of good reading skills in schools. The major findings of the study were students' general lack of motivation to read and their restrictive choice of reading texts 
(they read more texts such as newspapers from Botswana and the rest of the African continent than any other texts, including English or American texts). Factors such as teaching literature in schools, creating interactive English classes, making books available and motivating students to read via relevant challenging reading assignments were highlighted as crucial for the improvement of students' reading skills. In another study, Arua et al. (2005) focused on literacy skills instruction and assessment in junior secondary schools in Botswana. One of the key findings of the study was that only a handful of the students had the requisite productive and receptive skills in their first year of junior secondary education. In addition, the study indicates that, though the Revised National Policy on Education (RNPE) (1994 ${ }^{3}$ ) stipulates that pupils should be instructed in English from standard 2, English is used as a medium of instruction together with local languages including Setswana, Ikalanga or Shekhalahari. What these two studies show is that students in public high schools are grossly deficient in their reading comprehension skills, which implies that the situation in public primary schools is unlikely to be better.

The Botswana Examinations Council (BEC) study (2014), conducted under the guidelines of the Progress in International Reading Literacy Study (PIRLS, 2011), an international assessment of reading at standard 4 conducted every five years by the International Association for the Evaluation of Educational Achievement (IEA), provides insightful findings. Both PIRLS and pre-PIRLS are international comparability studies which generate information on curriculum implementation, contexts of learning and successful pedagogical practice across all participating countries (BEC PIRLS report, 2014: 48). The BEC PIRLS study focused on two purposes of reading, namely reading for literary experience and reading to acquire and use information. The study revealed that Batswana pupils performed better in acquiring information, with a mean score of 466, than in literary experience, with a mean score of 459 (BEC PIRLS report, 2014:49). Overall (as well as in reading), girls performed better than boys. The study also revealed that sociocultural factors, including the use of English at home, high home possessions, high support for student learning and the availability of more books at home, enhanced reading comprehension. The literature surveyed above clearly indicates that no empirical study has been conducted to compare and understand the differential reading comprehension competencies of public schools and private schools specifically at primary school level in Botswana, and this was the impetus for this study.

Literature from different parts of the world comparing the results of public and private schools in general indicates that private school learners do better in many subjects than public school learners. For example, Peterson and Llaudet (2006) report that, based on the 2003 National Assessment of Educational Progress data, private school learners performed better in both mathematics and reading in the United States of America (USA). Similarly, Lubienski and Lubienski (2006), who compared the academic performance of private, charter and public school learners in the USA, concluded that private school learners scored higher than both charter and public school learners in national examinations. Braun, Jenkins and Grigg (2006) investigated the performance of fourth and eighth graders in mathematics and reading in both private and public schools in the USA, and concluded that the difference in the mean scores between private and public schools was statistically significant, with private schools achieving higher mean scores.

Adeyemi's (2014) comparison of the academic performance of private and public schools in Ilesa East and West Local Government Council Areas of Osun State in Nigeria in three core subjects, namely mathematics, social studies and English, corroborates the findings of other studies cited above. In the three subjects investigated, $73.3 \%$ of the pupils from the private 
schools scored above average, compared to only 30.8\% in public schools. Ochenje (2015) also compared the performance of standard 4 pupils in private and public schools in the Kitale Municipality in Kenya in five subjects, namely English, Kiswahili, mathematics, science and social studies. Based on the comparison of the mean scores per subject for each group, Ochenje's (2015) findings support previous studies indicating that private school pupils perform better than public school pupils.

\section{METHODOLOGY}

\section{Sampling}

As indicated earlier, this paper reports on an aspect of a much larger study, which compares the reading comprehension of pupils in private and public schools located in two different settings - rural and urban. The population for the study comprised standard 4 pupils from four schools, two private and two public, in urban and rural settings in Botswana. It is important to note that research findings in different climes have noted the urban-rural gap in the reading skills of pupils; rural school learners are considered to be at risk. For example, in the Programme for International Student Assessment, Canadian students from urban schools were reported to have performed better than those from rural schools (Cartwright \& Allen, 2002). Also, in recognition of the unique needs of rural school districts, Arnold et al. (2005: 18) urge scholars working on rural education to pay particular attention to improving teachers' 'pedagogical skills in ways that have the greatest impact on student achievement' (see also Nel, 2011).

Thus, in terms of choice of location, we purposively selected an urban and a rural setting, Gaborone and Thamaga ${ }^{4}$ respectively. Gaborone is the capital city of Botswana, with more than eight public primary schools and more than 10 private schools. Thamaga is a village some $50 \mathrm{~km}$ away from Gaborone, with three public primary schools and two private ones. To select the specific schools, we randomly selected two schools each, one private and one public, from Thamaga and Gaborone. In all, 378 pupils in the four schools participated in the study, distributed as follows: Thamaga Public: 89; Thamaga Private: 68, Gaborone Public: 94 and Gaborone Private: 127. The variation in the number of students reported for each school is due to the fact that each school had different enrolment figures in their standard 4 streams. Out of the 378 pupils, $38 \%$ of the respondents were male, $38 \%$ were female and the remaining $23 \%$ did not indicate their gender.

\section{Ethical issues}

Research involving human subjects has become much more scrutinised to ensure that researchers do not advertently or inadvertently violate participants' rights. The study reported in this paper was funded by the University of Botswana's Office of Research and Development. As such, the researchers complied with that institution's stipulations governing the administration of research instruments to the subjects of the study. Firstly, after presenting their detailed proposal highlighting its benefits to the entire school system, the researchers obtained a written permission from the Ministry of Education and Skills Development to conduct the study in the schools. Thereafter, the researchers visited the schools to explain the nature of the research as well as the instruments to be used to each school head, who in turn communicated with the teachers. Letters of consent were written and given to the pupils to take to their parents to give consent that their children may take part in the study. One of the 
very important issues raised in the schools was keeping the identity of each participating school anonymous.

In each class, before the research instruments were administered to both the teachers and the pupils, the researchers addressed the pupils and explained in detail to them the nature of the research and what is expected of them. Participation by individual teachers and pupils was entirely voluntary.

\section{Comprehension test and administration}

As noted earlier, this paper reports on an aspect of a much larger study for which a standardised test and two sets of questionnaires were utilised as data gathering instruments. However, since the main objective of this aspect of the study was to compare the English reading comprehension abilities of pupils of four primary schools (both public and private) in Botswana, we report only on the standardised English reading comprehension exercise which was administered to the pupils in these schools. Regarding standardised tests which have been developed to investigate reading comprehension, we examine those of Herbers et al. (2012) and August et al. (2006). Herbers et al (2012: 367) studied the:

predictive significance of an oral reading assessment (ORA) in first grade as an early indicator of academic risk and as a moderator of risks associated with mobility and poverty for later learning, indexed by achievement in third grade and subsequent growth in both reading and math.

The ORA (Herbers, 2012: 367) as a standardised test requires students to read aloud three passages to determine their 'reading ability and fluency in first grade', which are measured as 'average words read aloud per minute'. Although our perspective of reading comprehension recognises that fluency is crucial, our test in this study excluded oral fluency.

August et al. (2006: 221) developed the Diagnostic Assessment of Reading Comprehension (DARC), which aims to 'reflect central comprehension processes while minimising decoding and language demands', and observes that DARC is based on the assessment instrument earlier developed by Potts and Peterson (1985) and 'extended by Hannon and Daneman (2001)'. The four major components of reading comprehension that DARC aims to assess are remembering newly read text, making inferences licensed by the text, accessing relevant background knowledge, and making inferences that require integrating background knowledge with the text. Though DARC was piloted on pupils from second grade through sixth grade and could be adapted for our study, we opted to adapt a different test, which we believe to be more culturally relevant to our subjects, albeit retaining three of the components of reading comprehension outlined above: extracting information, making inferences and interpreting information.

Our test, which was first piloted in a public school and a private school, comprised 10 questions based on a passage titled How the Chipmunk got its stripes (Pearson Longman Tests). Out of these 20 questions, six were multiple-choice, while the remaining four, which were open-ended, allowed the pupils to express themselves. In general, the questions tested the learners' decoding skills (involving reading words accurately and accessing lexical representations). They also tested the learners' knowledge in vocabulary, linguistic structure, discourse and world knowledge. Finally, the questions drew on the learners' cognitive 
processing capacities, particularly accessing relevant background knowledge and drawing justified inferences.

The tests were administered in the pupils' home classrooms in each school. The English teacher distributed the questionnaire to the pupils, while the investigators sat at the back of the classroom to avoid intruding and to take notes on the general atmosphere of each class. The teacher explained that this was a reading comprehension activity and that the pupils should answer all the questions to the best of their ability. Generally, the pupils in the private schools took 30 to 45 minutes to complete the task, while those in the public schools took close to an hour to complete it. The investigators then collected the scripts from the teachers and both investigators read through and graded each script.

\section{Validity and reliability}

The test, which was obtained from the Pearson Longman website (Pearson-Longman Tests) was modified to make it more suitable to the learners culturally and socially in terms of its theme. As part of the measures taken to ensure that the rubrics were clear and that the passage actually tested what it was designed to test, two colleagues assisted in evaluating it, and their suggestions relating to re-ordering and rephrasing the questions were included in the final version of the test. In addition, our observations from the pilot run were used as input to improve the final version of the test. Furthermore, to ensure that the choice of words matched the cognitive level of the pupils, the comprehension passage was run through a text analyser for readability on a scale of 100 to 20 , where 100 is easy and 20 is difficult. Its readability score was $71.9 \%$, indicating that the text was easy to read. Based on the pilot test as well as these other measures, including keeping the conditions under which the test was administered in all the schools fairly constant, we believe that the test is valid and that its results are reliable.

\section{Grading of test answers}

As already indicated, we were particularly keen on the learners' memory for text through their recapitulation of basic information from a text, their ability to access relevant background knowledge by extracting information from a text, and their ability to draw justified inferences from a text. The multiple-choice items were fairly easy to grade. However, the four items which demanded that the pupils express themselves were challenging, particularly because some of the pupils' answers were incomprehensible.

For purposes of quality assurance, both investigators graded each pupil's script and their total marks were compiled and recorded. The pupils' scores in each question were entered into SPSS. For ease and consistency of analysis, the pupils' scores in the open-ended questions were ranked on a scale of 0-2 with 0.5 intervals. In addition to simple percentages, tests of means were used to analyse the data. Our results are presented and discussed in the following section.

\section{FINDINGS AND DISCUSSION}

As indicated earlier, the main objective of the study was to compare the reading comprehension levels of standard 4 pupils in public and private schools. Specifically, we addressed two research questions, namely: Are there significant differences between the comprehension abilities of (a) public and private school pupils, (b) rural and urban private 
school pupils, and (c) urban and rural public school pupils? What implications, if any, do the differential abilities have for the pupils' academic success?

In our presentation of findings and discussion, we address each of these questions in turn beginning with the first. As noted previously, our test was designed to measure the pupils' reading comprehension based on three sub-skills: the ability to extract information from the text, ability to make inference and ability to interpret text. Three of the comprehension questions, namely questions 1,3 and 5, demanded that the pupils extract answers directly from the passage. Questions 2, 4, 6, 7 and 8 required them to make inferences, while questions 9 and 10 required them to interpret the information provided in the text and respond in their own words.

\section{Comprehension: extraction of information}

Findings with respect to the ability of the pupils to extract information from the text indicate that the urban private school pupils obtained the highest set of scores, except for question 5, where the rural private school pupils did slightly better. However, the urban private school pupils' mean score for their ability to extract information correctly from the text was highest, at $77.8 \%$, followed by the rural private school pupils, with a mean score of $65.2 \%$. The rural and urban public school pupils obtained mean scores of $35.7 \%$ and $47.6 \%$ respectively.

Table 1: Measure of pupils' ability to extract information (questions 1,3 and 5) $N=378^{a}$

\begin{tabular}{|c|c|c|c|c|c|c|c|c|c|}
\hline \multirow{2}{*}{ Question } & \multirow{2}{*}{ Answer } & \multicolumn{2}{|c|}{ Rural/public } & \multicolumn{2}{|c|}{$\begin{array}{l}\text { Rural/privat } \\
\text { e }\end{array}$} & \multicolumn{2}{|c|}{ Urban/publi } & \multicolumn{2}{|c|}{ Urban/private } \\
\hline & & Freq & $\%$ & Freq & $\%$ & Freq & $\%$ & Freq & $\%$ \\
\hline $\begin{array}{l}\text { 1. Theme } \\
\text { of the } \\
\text { story }\end{array}$ & $\begin{array}{l}\text { Stand up for } \\
\text { what you } \\
\text { believe in }\end{array}$ & $\begin{array}{l}16 \\
N=8 \\
9\end{array}$ & 18.0 & $\begin{array}{l}24 \\
N=6 \\
6\end{array}$ & 36.4 & $\begin{array}{l}26 \\
N=9 \\
3\end{array}$ & 28.0 & $\begin{array}{l}74 \\
N=12 \\
3\end{array}$ & 60.2 \\
\hline $\begin{array}{l}\text { 3. What } \\
\text { does } \\
\text { 'chattered' } \\
\text { mean? }\end{array}$ & $\begin{array}{l}\text { Talked } \\
\text { continuousl } \\
\mathrm{y}\end{array}$ & $\begin{array}{l}31 \\
N=8 \\
9\end{array}$ & 34.8 & $\begin{array}{l}42 \\
N=6 \\
6\end{array}$ & 63.6 & $\begin{array}{l}42 \\
N=9 \\
4\end{array}$ & 44.7 & $\begin{array}{l}98 \\
N=12 \\
4\end{array}$ & 79.0 \\
\hline $\begin{array}{l}5 . \text { Where } \\
\text { does the } \\
\text { story take } \\
\text { place? }\end{array}$ & $\begin{array}{l}\text { On a } \\
\text { mountain } \\
\text { top }\end{array}$ & $\begin{array}{l}47 \\
N=8 \\
7\end{array}$ & 54.0 & $\begin{array}{l}63 \\
N=6 \\
6\end{array}$ & 95.5 & $\begin{array}{l}65 \\
N=9 \\
2\end{array}$ & 70.0 & $\begin{array}{l}116 \\
N=12 \\
3\end{array}$ & 94.3 \\
\hline $\begin{array}{l}\text { Mean } \\
\text { score }\end{array}$ & & 31.3 & 35.6 & 43 & 65.2 & 44.3 & 47.6 & 96 & 77.8 \\
\hline
\end{tabular}

a. Although the total number of pupils who participated in the study was 378 , frequencies in percentages are calculated on the basis of the number who answered each question as shown in Tables 1 and $2 \mathrm{a}$.

\section{Comprehension: inference}

Table 2a below presents results of pupils' ability to infer. The inference skill was tested through questions 2, 6 and 7 . 
Table 2a: Measure of pupils' ability to infer (questions 2, 6 and 7)

\begin{tabular}{|c|c|c|c|c|c|c|c|c|c|}
\hline \multirow{2}{*}{ Question } & \multirow{2}{*}{ Answer } & \multicolumn{2}{|c|}{ Rural/public } & \multicolumn{2}{|c|}{ Rural/private } & \multicolumn{2}{|c|}{ Urban/public } & \multicolumn{2}{|c|}{ Urban/private } \\
\hline & & Freq & $\%$ & Freq & $\%$ & Freq & $\%$ & Freq & $\%$ \\
\hline $\begin{array}{l}\text { 2. What is } \\
\text { Bear like? }\end{array}$ & $\begin{array}{l}\text { He is used } \\
\text { to getting } \\
\text { his way }\end{array}$ & $\begin{array}{l}20 \\
N=8 \\
9\end{array}$ & 22.5 & $\begin{array}{l}24 \\
N=6 \\
7\end{array}$ & 35.8 & $\begin{array}{l}25 \\
\mathrm{~N}=9 \\
4\end{array}$ & 26.6 & $\begin{array}{l}79 \\
N=12 \\
4\end{array}$ & 63.2 \\
\hline $\begin{array}{l}6 . \quad \text { What } \\
\text { happened } \\
\text { after } \\
\text { Chipmunk's } \\
\text { argument } \\
\text { with Bear? }\end{array}$ & $\begin{array}{l}\text { The } \\
\text { animals } \\
\text { saw their } \\
\text { first } \\
\text { sunrise } \\
\text { ever }\end{array}$ & $\begin{array}{l}20 \\
N=8 \\
6\end{array}$ & 23.3 & $\begin{array}{l}45 \\
N=6 \\
5\end{array}$ & 69.2 & $\begin{array}{l}41 \\
N=9 \\
0\end{array}$ & 45.6 & $\begin{array}{l}102 \\
N=12 \\
4\end{array}$ & 82.3 \\
\hline $\begin{array}{l}\text { 7. What is } \\
\text { the antonym } \\
\text { for the word } \\
\text { argued? }\end{array}$ & Agreed & $\begin{array}{l}38 \\
N=8 \\
6\end{array}$ & 44.2 & $\begin{array}{l}22 \\
N=6 \\
6\end{array}$ & 33.3 & $\begin{array}{l}35 \\
\mathrm{~N}=9 \\
2\end{array}$ & 38.0 & $\begin{array}{l}31 \\
N=12 \\
2\end{array}$ & 25.0 \\
\hline Mean score & & 26 & 30 & 30.3 & 46.1 & 33.7 & 36.7 & 70.7 & 56.8 \\
\hline
\end{tabular}

The questions on inference were of two types. In the first set of questions, questions 2, 6 and 7 , the pupils were required to make deductions from the text. However, in each of these questions, they were presented with a set of answers from which they were to select the one that best reflected their deductions (See Table $2 \mathrm{a}$ for the results). In the second set, questions 4 and 8, they were required to express their deductions in their own words (see Tables $2 \mathrm{~b}$ and $2 \mathrm{c}$ ), and their responses were graded and rated on a scale of $0-2$, with 0.5 intervals. As shown in Table 2a, the urban private school pupils obtained the highest mean score $(56.8 \%)$ for inference involving selecting an answer that best reflects their deductions, followed by the rural private school pupils $(46.1 \%)$. The urban public school pupils were third with a mean score of $36.7 \%$, while the rural public school pupils ranked lowest with a mean score of $30 \%$.

Table $2 \mathrm{~b}$ summarises the pupils' answers to question 4 , which required them to make a deduction from the story.

Table 2b: Measure of pupils' ability to infer (question 4)

\begin{tabular}{|l|l|l|l|l|l|l|l|l|l|l|}
\hline \multirow{3}{*}{ Marks } & \multicolumn{2}{l}{$\begin{array}{l}\text { Rural/publi } \\
\text { c }\end{array}$} & \multicolumn{2}{l|}{ Rural/private } & \multicolumn{2}{l|}{ Urban/public } & \multicolumn{2}{l|}{ Urban/private } & \multicolumn{2}{l|}{ Total } \\
\cline { 2 - 12 } & Freq & $\%$ & Freq & $\%$ & Freq & $\%$ & Freq & $\%$ & Freq & $\%$ \\
\hline 0 & 53 & 61.6 & 31 & 47.0 & 67 & 71.3 & 40 & 32.8 & 191 & 51.9 \\
\hline 0.5 & 6 & 7.0 & 2 & 3.0 & 0 & 0.0 & 5 & 4.1 & 13 & 3.5 \\
\hline 1.0 & 3 & 3.5 & 1 & 1.5 & 1 & 1.1 & 9 & 7.4 & 14 & 3.8 \\
\hline 1.5 & 2 & 2.3 & 0 & 0.0 & 0 & 0.0 & 0 & 0.0 & 2 & 0.5 \\
\hline 2.0 & 22 & 25.6 & 32 & 48.5 & 26 & 27.7 & 68 & 55.7 & 148 & 40.2 \\
\hline Subtotal $^{\mathrm{a}}$ & 33 & 38.4 & 35 & 53 & 27 & 28.8 & 82 & 67.2 & 177 & 47.5 \\
\hline Grand total $^{\mathrm{a}}$ & 86 & 100 & 66 & 100 & 94 & 100 & 122 & 100 & 368 & 100 \\
\hline
\end{tabular}

a. Subtotal is the number of pupils who scored between 1 and 2, while grand total is the overall number of pupils, including those who scored 0 .

The urban private school students performed best in this skill area, with $55.7 \%$ of them obtaining the maximum mark of 2 for this question, followed by $48.5 \%$ of the rural private school pupils. Only $27.7 \%$ and $25.6 \%$ of the pupils in the urban and rural public schools 
respectively scored the maximum mark for this question. In terms of those who scored 0 for this question, the urban and rural public school pupils recorded the highest percentages, $71.3 \%$ and $61.6 \%$ respectively, compared to their counterparts in the urban and rural private schools, with $32.8 \%$ and $47 \%$ respectively. This implies that many more of the pupils in the public schools were unable to answer this question, an indication that they were generally less capable of making inferences from text. Overall, the urban and rural private school pupils obtained mean scores of $67.2 \%$ and $53 \%$ respectively, while the urban and rural public school pupils obtained $28.8 \%$ and $38.4 \%$ respectively.

With respect to Table 2c, the inferential task demanded of the pupils was of a higher order; the pupils were expected to deduce from the story how Chipmunk's attitude was different from that of the other animals.

Table 2c: Measure of pupils' ability to infer (question 8)

\begin{tabular}{|l|l|l|l|l|l|l|l|l|l|l|l|}
\hline \multirow{2}{*}{ Marks } & \multicolumn{2}{|l|}{ Rural/public } & \multicolumn{2}{l|}{ Rural/private } & \multicolumn{2}{|l|}{ Urban/public } & \multicolumn{2}{|l|}{ Urban/private } & \multicolumn{2}{l|}{ Total } \\
\cline { 2 - 13 } & Freq & $\%$ & Freq & $\%$ & Freq & $\%$ & Freq & $\%$ & Freq & $\%$ \\
\hline 0 & 64 & 72.7 & 46 & 68.7 & 80 & 86.0 & 85 & 69.7 & 275 & $\begin{array}{l}74 . \\
3\end{array}$ \\
\hline 0.5 & 2 & 2.3 & 3 & 4.5 & 0 & 0.0 & 3 & 2.5 & 8 & 2.2 \\
\hline 1.0 & 13 & 14.8 & 9 & 13.4 & 8 & 8.6 & 18 & 14.8 & 48 & $\begin{array}{l}13 . \\
0\end{array}$ \\
\hline 1.5 & 3 & 3.4 & 0 & 0.0 & 0 & 0.0 & 0 & 0.0 & 3 & 0.8 \\
\hline 2.0 & 6 & 6.8 & 9 & 13.4 & 5 & 5.4 & 16 & 13.1 & 36 & 9.7 \\
\hline Subtotal & 24 & 27.3 & 21 & 31.3 & 13 & 14 & 37 & 30.3 & 95 & $\begin{array}{l}25 . \\
7\end{array}$ \\
\hline Grand total & 88 & 100 & 67 & 100 & 93 & 100 & 122 & 100 & 370 & 100 \\
\hline
\end{tabular}

The results show that the performance in this question was very low across the board; only $13.4 \%$ and $13.1 \%$ of the rural and urban private school pupils respectively scored the maximum mark for this question, while only $6.8 \%$ and $5.4 \%$ of rural and urban public school pupils scored the maximum mark for this question. Overall, the mean scores for the rural and urban private school pupils were $31.3 \%$ and $30.4 \%$ respectively, while those for the rural and urban public school pupils were $27.3 \%$ and $14.0 \%$ respectively.

The results presented with respect to the pupils' abilities to make inferences are quite interesting, more so because the task required them not only to make deductions but also to express such with clarity. Many of the urban public school pupils gave answers that were absolutely incomprehensible, whereas their counterparts in the rural public school were capable of expressing themselves in a much better manner. Fewer pupils from the rural public school produced sentences which were incomprehensible. While inference as an aspect of reading comprehension makes more demand of pupils' cognitive ability, our findings show that those in the rural public, rural private and urban private schools were better predisposed to doing this task than those in the urban public school.

\section{Comprehension: interpretation of information}

The third measure of the pupils' reading comprehension in this study was their ability to interpret information. Two of the questions in the test focused on this, namely: 'How did Chipmunk win the argument with Bear?' and 'What lessons can we learn from Chipmunk? 
Use details from the story.' For these two questions, the pupils' answers were rated on a scale of 0 to 2 , with 0.5 intervals. The results are presented in Tables $3 \mathrm{a}$ and $3 \mathrm{~b}$.

Table 3a: Pupils' ability to interpret information (question 9)

\begin{tabular}{|l|l|l|l|l|l|l|l|l|l|l|}
\hline \multirow{2}{*}{ Marks } & \multicolumn{2}{l}{ Rural/public } & \multicolumn{2}{l|}{ Rural/private } & \multicolumn{2}{l|}{ Urban/public } & \multicolumn{2}{l|}{ Urban/private } & \multicolumn{2}{l|}{ Total } \\
\cline { 2 - 14 } & Freq & $\%$ & Freq & $\%$ & Freq & $\%$ & Freq & $\%$ & Freq & $\%$ \\
\hline 0 & 63 & 70.8 & 30 & 45.5 & 74 & 79.6 & 72 & 59.5 & 239 & 64.8 \\
\hline 0.5 & 5 & 5.6 & 6 & 9.1 & 0 & 0.0 & 6 & 5.0 & 17 & 4.6 \\
\hline 1.0 & 12 & 13.5 & 24 & 36.4 & 12 & 12.9 & 40 & 33.1 & 88 & 23.8 \\
\hline 1.5 & 0 & 0.0 & 0 & 0.0 & 0 & 0.0 & 0 & 0.0 & 0 & 0.0 \\
\hline 2.0 & 9 & 10.1 & 6 & 9.1 & 7 & 7.5 & 3 & 2.5 & 25 & 6.8 \\
\hline Subtotal & 26 & 29.2 & 36 & 54.6 & 19 & 20.4 & 49 & 40.6 & 130 & 35.2 \\
\hline Grand total & 89 & 100 & 66 & 100 & 93 & 100 & 121 & 100 & 369 & 100 \\
\hline
\end{tabular}

Table 3a shows that the rural private school pupils ranked highest, with a mean score of $54.6 \%$, followed by the urban private school pupils, with $40.6 \%$, while the rural and urban public school pupils obtained $30.2 \%$ and $20.4 \%$ respectively in answering the question on how Chipmunk won the argument with Bear.

Table $3 \mathrm{~b}$ indicates the performance of the pupils in relating the moral of the story.

Table 3b: Pupils' ability to interpret information (question 10)

\begin{tabular}{|l|l|l|l|l|l|l|l|l|l|l|}
\hline \multirow{2}{*}{ Marks } & \multicolumn{2}{l}{ Rural/public } & \multicolumn{2}{l|}{ Rural/private } & \multicolumn{2}{l|}{ Urban/publi } & \multicolumn{2}{l|}{ Urban/private } & \multicolumn{2}{l|}{ Total } \\
\cline { 2 - 14 } & Freq & $\%$ & Freq & $\%$ & Freq & $\%$ & Freq & $\%$ & Freq & $\%$ \\
\hline 0 & 70 & 79.6 & 34 & 51.5 & 84 & 90.3 & 59 & 49.2 & 247 & 67.3 \\
\hline 0.5 & 9 & 10.2 & 3 & 4.5 & 0 & 0.0 & 3 & 2.5 & 15 & 4.1 \\
\hline 1.0 & 9 & 10.2 & 18 & 27.3 & 3 & 3.2 & 22 & 18.3 & 52 & 14.2 \\
\hline 1.5 & 0 & 0.0 & 0 & 0.0 & 0 & 0.0 & 0 & 0.0 & 0 & 0.0 \\
\hline 2.0 & 0 & 0.0 & 11 & 16.7 & 6 & 6.5 & 36 & 30.0 & 53 & 14.4 \\
\hline Subtotal & 18 & 20.4 & 32 & 48.5 & 9 & 9.7 & 61 & 50.8 & 120 & 32.7 \\
\hline Grand total & 88 & 100 & 66 & 100 & 93 & 100 & 120 & 100 & 367 & 100 \\
\hline
\end{tabular}

The urban private school pupils ranked highest, with a mean score of $50.8 \%$, followed by their counterparts in the rural private school, who obtained $48.5 \%$. The rural and urban public school pupils scored $20.5 \%$ and $9.7 \%$ respectively in relating the moral of the story. We note again that the performance of the urban public school pupils was the lowest.

The results of the pupils in interpreting information were illuminating, as the question involved making inferences. In order to interpret information, which requires higher-order skills, the pupils needed to be able to synthesise the information contained in the text. They also needed to engage their creative instincts to fuse or combine information together and express it in an intelligible manner. It is striking that the rural private school pupils exhibited greater success with this skill than their counterparts in the urban private school. A probable reason for this difference between the rural and urban private school pupils' performance in this skill may be connected with class size. The average class size in the urban private school was 32 , while it was 23 in the rural private school. Perhaps the teachers in the rural private school interacted more closely with and devoted more attention to their pupils. 
The findings from the pupils' comprehension abilities using the three sub-skills of extraction of information, inference and interpretation indicate that those in the rural and urban private schools were more adept at these three components of reading comprehension than their counterparts in the public schools. This result is in consonance with those of Peterson and Llaudet (2006), Lubienski and Lubienski (2006), Braun, Jenkins and Grig (2006), Adeyemi (2014), and Ochenje (2015). Also, as Adams (1990), Gough and Tunmer (1986), and Vellutino $(1979,1987)$ note, inaccurate word reading, which is closely associated with poverty, is one of the causes of poor performance in reading comprehension. Similarly, Van Vechten (2013), Kieffer and Lesaux (2012), and Chen and Tutwiler (2017) note that students from low socioeconomic environments are behind in their reading levels, while Uccelli et al. (2015) observe that, on average, students from higher socioeconomic background families performed better than those from lower socioeconomic backgrounds. While we cannot generalise that the pupils in the public schools were all from poor homes, it is likely that many more of them were from homes where parents struggled to make ends meet compared with their counterparts in the private schools. This has an implication for whether or not the pupils read at home. Children from economically stable homes are likely to have more reading opportunities beyond the classroom. Furthermore, our classroom observation of the pupils while they were doing the test revealed that pupils in the public schools indulged more in vocalisation, which could also lead to inaccurate word reading and, in turn, poor performance.

Between the two private schools, however, the pupils in the rural school were more skilled at making inferences and interpreting information. Also, between the two public schools, the rural pupils were more skilled at the three components of reading comprehension measured by the test than their urban peers. Though this latter result seems atypical, our general observation indicated that the school environment and the demeanour of the teachers in the rural public schools appeared more conducive to learning than in the urban public school.

\section{Tests of significance}

In this section, we present the results of the test for equality of means to ascertain whether the comprehension abilities of the pupils reported above were significantly different. First, we compared the pupils in the private and the public schools to see whether their reading comprehension abilities differed significantly, as indicated by their answers to all the questions. The test results are presented in Table 4. 
Table 4: T-test, private and public schools compared

\begin{tabular}{|c|c|c|c|c|c|c|c|}
\hline \multirow[b]{3}{*}{ Questions } & \multicolumn{7}{|c|}{ T-test for equality of means } \\
\hline & \multirow[t]{2}{*}{$\mathrm{t}$} & \multirow[t]{2}{*}{$\mathrm{df}$} & \multirow{2}{*}{$\begin{array}{l}\text { Sig. } \\
2- \\
\text { tailed }\end{array}$} & \multirow{2}{*}{$\begin{array}{l}\text { Mean } \\
\text { differenc } \\
\mathrm{e}\end{array}$} & \multirow{2}{*}{$\begin{array}{l}\text { Std. err } \\
\text { differenc } \\
\text { e }\end{array}$} & \multicolumn{2}{|c|}{$\begin{array}{ll}95 \% & \mathrm{Cl} \\
\text { difference }\end{array}$} \\
\hline & & & & & & Lower & Upper \\
\hline 1. Theme of the story. & 2.782 & $\begin{array}{l}36 \\
9\end{array}$ & 0.006 & 0.319 & 0.115 & 0.094 & 0.545 \\
\hline 2. What is the bear like? & 3.293 & $\begin{array}{l}37 \\
3\end{array}$ & 0.001 & 0.345 & 0.105 & 0.139 & 0.551 \\
\hline $\begin{array}{l}\text { 3. What does 'chattered' } \\
\text { mean? }\end{array}$ & -5.771 & $\begin{array}{l}37 \\
1\end{array}$ & 0.000 & -0.556 & 0.096 & -0.745 & -0.367 \\
\hline $\begin{array}{l}\text { 4. Why do chipmunks } \\
\text { have stripes on their } \\
\text { backs? }\end{array}$ & -5.421 & $\begin{array}{l}36 \\
6\end{array}$ & 0.000 & -0.79 & 0.146 & -1.077 & -0.503 \\
\hline $\begin{array}{l}\text { 5. Where does the story } \\
\text { take place? }\end{array}$ & -6.643 & $\begin{array}{l}36 \\
6\end{array}$ & 0.000 & -0.52 & 0.078 & -0.674 & -0.366 \\
\hline $\begin{array}{l}\text { 6. What happened after } \\
\text { Chipmunk's argument with } \\
\text { Bear? }\end{array}$ & 7.889 & $\begin{array}{l}36 \\
3\end{array}$ & 0.000 & 0.775 & 0.098 & 0.582 & 0.968 \\
\hline $\begin{array}{l}\text { 7. What is an antonym for } \\
\text { the word 'argued'? }\end{array}$ & -6.825 & $\begin{array}{l}36 \\
6\end{array}$ & 0.000 & -0.753 & 0.11 & -0.97 & -0.536 \\
\hline $\begin{array}{l}\text { 8. In what way is } \\
\text { Chipmunk's attitude } \\
\text { different from the other } \\
\text { animals? }\end{array}$ & -2.115 & $\begin{array}{l}36 \\
8\end{array}$ & 0.035 & -0.216 & 0.102 & -0.418 & -0.015 \\
\hline $\begin{array}{l}\text { 9. How did Chipmunk win } \\
\text { the argument with Bear? }\end{array}$ & -1.83 & $\begin{array}{l}36 \\
7\end{array}$ & 0.068 & -0.164 & 0.09 & -0.341 & 0.012 \\
\hline $\begin{array}{l}\text { 10. What lessons can we } \\
\text { learn from Chipmunk? }\end{array}$ & -7.289 & $\begin{array}{l}36 \\
5\end{array}$ & 0.000 & -0.772 & 0.106 & -0.981 & -0.564 \\
\hline
\end{tabular}

Table 4 indicates that the calculated t-values for all the questions were less than 0.05 , except for that of question 9, which was higher (0.068). The implication of this is that there was a significant difference in the pupils' comprehension abilities with respect to how they answered all the questions except question 9. Thus, the mean of the scores of the pupils in the private schools was significantly higher than that of the pupils in the public schools. The performance of the pupils in the private schools, measured in terms of their comprehension abilities, was therefore significantly different from the performance of those in the public schools. This result is in consonance with the finding of Braun et al. (2006) referred to earlier.

As previously indicated, the pupils' performance in question 9, which was used to measure their ability to interpret information, was very low, as $64.85 \%$ of all the pupils scored 0 in this particular question. Except for the rural private school, about $50 \%$ of the pupils in each school scored 0 in this question. Furthermore, the task of interpreting information is more cognitively demanding, so the pupils were required to produce their answers in their own words. Our finding in this respect affirms Arua et al.'s (2005) finding that only a handful of the students had the requisite productive and receptive skills in their first year of junior secondary education. The finding further underscores the importance of strengthening the teaching of reading in all schools, private and public, in the country. 
Because the means of the pupils in the rural public school were generally higher than those of their peers in the urban public school, we tested those scores to ascertain whether or not the two groups of pupils were significantly different. Similarly, we compared the pupils in the two private schools to see whether they were significantly different in terms of their comprehension abilities. The results of the test of significance for both sets of pupils are presented in Tables 5 and 6.

Table 5: T-test, urban and rural public schools compared

\begin{tabular}{|c|c|c|c|c|c|c|c|}
\hline \multirow[b]{3}{*}{ Questions } & \multicolumn{7}{|c|}{ T-test for equality of means } \\
\hline & \multirow{2}{*}{$\mathrm{t}$} & \multirow{2}{*}{ df } & \multirow{2}{*}{$\begin{array}{l}\text { Sig. } \\
2- \\
\text { tailed }\end{array}$} & \multirow{2}{*}{$\begin{array}{l}\text { Mean } \\
\text { differenc } \\
\mathrm{e}\end{array}$} & \multirow{2}{*}{$\begin{array}{l}\text { Std. err } \\
\text { differenc } \\
\text { e }\end{array}$} & \multicolumn{2}{|c|}{$\begin{array}{ll}95 \% & C \\
\text { difference }\end{array}$} \\
\hline & & & & & & $\begin{array}{l}\text { Lowe } \\
\mathrm{r}\end{array}$ & Upper \\
\hline 1. Theme of the story. & 1.863 & $\begin{array}{l}18 \\
0\end{array}$ & 0.064 & 0.278 & 0.149 & -0.016 & 0.573 \\
\hline 2. What is the bear like? & -0.75 & $\begin{array}{l}18 \\
1\end{array}$ & 0.454 & -0.131 & 0.174 & -0.475 & 0.213 \\
\hline $\begin{array}{l}\text { 3. What does 'chattered' } \\
\text { mean? }\end{array}$ & 0.242 & $\begin{array}{l}18 \\
1\end{array}$ & 0.809 & 0.04 & 0.167 & -0.289 & 0.37 \\
\hline $\begin{array}{l}\text { 4. Why do chipmunks } \\
\text { have stripes on their } \\
\text { backs? }\end{array}$ & 0.952 & $\begin{array}{l}17 \\
8\end{array}$ & 0.342 & 0.194 & 0.204 & -0.209 & 0.598 \\
\hline $\begin{array}{l}\text { 5. Where does the story } \\
\text { take place? }\end{array}$ & -1.447 & $\begin{array}{l}17 \\
7\end{array}$ & 0.150 & -0.203 & 0.14 & -0.48 & 0.074 \\
\hline $\begin{array}{l}\text { 6. What happened after } \\
\text { Chipmunk's argument with } \\
\text { Bear? }\end{array}$ & 1.827 & $\begin{array}{l}17 \\
4\end{array}$ & 0.069 & 0.282 & 0.154 & -0.023 & 0.586 \\
\hline $\begin{array}{l}\text { 7. What is an antonym for } \\
\text { the word 'argued'? }\end{array}$ & -1.441 & $\begin{array}{l}17 \\
6\end{array}$ & 0.151 & -0.197 & 0.137 & -0.468 & 0.073 \\
\hline $\begin{array}{l}\text { 8. In what way is } \\
\text { Chipmunk's attitude } \\
\text { different from the other } \\
\text { animals? }\end{array}$ & 2.141 & $\begin{array}{l}17 \\
9\end{array}$ & 0.034 & 0.287 & 0.134 & 0.022 & 0.551 \\
\hline $\begin{array}{l}\text { 9. How did Chipmunk win } \\
\text { the argument with Bear? }\end{array}$ & 1.449 & $\begin{array}{l}18 \\
0\end{array}$ & 0.149 & 0.196 & 0.135 & -0.071 & 0.462 \\
\hline $\begin{array}{l}\text { 10. What lessons can we } \\
\text { learn from Chipmunk? }\end{array}$ & 0.773 & $\begin{array}{l}17 \\
9\end{array}$ & 0.441 & 0.081 & 0.105 & -0.126 & 0.288 \\
\hline
\end{tabular}

As indicated by the calculated t-values for all the questions, which were greater than 0.05 except for question 8 , there was no significant difference in the comprehension abilities of the pupils in the two public schools. However, that the calculated t-value for question 8 was less than 0.05 implies that the two sets of pupils differed significantly in terms of how they answered that question; therefore, they differed in their ability to make inferences. This confirms our earlier finding that the rural public school pupils are more adept in making inferences and interpreting information than their public school peers. 
Table 6: T-test, urban and rural private schools compared

\begin{tabular}{|c|c|c|c|c|c|c|c|c|}
\hline & \multirow[b]{2}{*}{ Sig. } & \multicolumn{5}{|c|}{ T-test for equality of means } & \multicolumn{2}{|c|}{ CI $95 \%$} \\
\hline & & $\mathrm{t}$ & df & $\begin{array}{l}\text { Sig 2- } \\
\text { tailed }\end{array}$ & $\begin{array}{l}\text { Mean } \\
\text { diff. }\end{array}$ & $\begin{array}{l}\text { Std. } \\
\text { error }\end{array}$ & $\begin{array}{l}\text { Lowe } \\
\mathbf{r}\end{array}$ & $\begin{array}{l}\text { Uppe } \\
\mathbf{r}\end{array}$ \\
\hline 1. Theme of the story & 0.025 & 3.486 & $\begin{array}{l}18 \\
7\end{array}$ & 0.001 & 0.612 & 0.176 & 0.266 & 0.959 \\
\hline 2. What is the bear like? & 0.199 & 3.161 & $\begin{array}{l}19 \\
0\end{array}$ & 0.002 & 0.388 & 0.123 & 0.146 & 0.631 \\
\hline $\begin{array}{ll}\text { 3. What does } \\
\text { 'chattered' mean? }\end{array}$ & 0.021 & -0.012 & $\begin{array}{l}18 \\
8\end{array}$ & 0.991 & -0.001 & 0.105 & -0.209 & 0.207 \\
\hline $\begin{array}{l}\text { 4. Why do chipmunks } \\
\text { have stripes on their } \\
\text { backs? }\end{array}$ & 0.015 & -1.370 & $\begin{array}{l}18 \\
6\end{array}$ & 0.172 & -0.298 & 0.217 & -0.726 & 0.131 \\
\hline $\begin{array}{l}\text { 5. Where does the story } \\
\text { take place? }\end{array}$ & 0.425 & 0.399 & $\begin{array}{l}18 \\
7\end{array}$ & 0.690 & 0.031 & 0.078 & -0.122 & 0.185 \\
\hline $\begin{array}{l}\text { 6. What happened after } \\
\text { Chipmunk's argument } \\
\text { with bear? }\end{array}$ & 0.000 & 2.167 & $\begin{array}{l}18 \\
7\end{array}$ & 0.031 & 0.277 & 0.128 & 0.025 & 0.530 \\
\hline $\begin{array}{l}\text { 7. What is an antonym } \\
\text { for the word 'argued'? }\end{array}$ & 0.015 & -3.704 & $\begin{array}{l}18 \\
8\end{array}$ & 0.000 & -0.642 & 0.173 & -0.984 & -0.300 \\
\hline $\begin{array}{l}\text { 8. In what way is } \\
\text { Chipmunk's attitude } \\
\text { different from the other } \\
\text { animals? }\end{array}$ & 0.691 & 0.229 & $\begin{array}{l}18 \\
7\end{array}$ & 0.819 & 0.037 & 0.160 & -0.279 & 0.352 \\
\hline $\begin{array}{l}\text { 9. How did Chipmunk } \\
\text { win the argument with } \\
\text { bear? }\end{array}$ & 0.039 & 2.569 & $\begin{array}{l}18 \\
5\end{array}$ & 0.011 & 0.314 & 0.122 & 0.073 & 0.555 \\
\hline $\begin{array}{l}\text { 10. What lessons can } \\
\text { we learn from } \\
\text { Chipmunk? }\end{array}$ & 0.004 & -1.417 & $\begin{array}{l}18 \\
4\end{array}$ & 0.158 & -0.270 & 0.190 & -0.645 & 0.106 \\
\hline
\end{tabular}

The calculated t-value for questions $1,3,6,7,9$ and 10 were less than 0.05 , indicating that there was a significant difference in the pupils' abilities in terms of their responses to these questions. Questions 1 and 3 were two of the questions dealing with extraction of information, while questions 6 and 7, and 9 and 10 dealt with making inferences and interpreting information. As indicated in Table 1, urban private school pupils obtained the highest set of scores in extracting information, except for question 5. The test result therefore confirms that the urban private school pupils were better at extracting information. With respect to questions 6 and 7, which dealt with testing the pupils' ability to draw inferences, the mean scores (Table 2a) indicated that the urban private school pupils obtained the highest mean score $(56.8 \%)$, followed by the private rural pupils $(46.1 \%)$. The t-test therefore confirms that the urban private were also better at selecting appropriate answers for questions that were inferential in nature than their rural counterparts. The t-test results for questions 9 and 10 , which dealt with interpretation, are illuminating because they strengthen our earlier claim that the rural private school pupils were better than their urban counterpart at the interpretation required in question 9 , as the difference between their mean score $(54.6 \%)$ and that of their urban counterparts $(40.6 \%)$ was significant. However, the urban private school pupils' mean score of $50.8 \%$, which was also significant, confirmed that they were better at relating the moral of the story, the focus of question 10, than their rural counterparts. 
In summary, the tests of significance have confirmed that, generally, urban and rural private school pupils had much better reading comprehension abilities. The tests of significance also showed that the rural public school pupils were much better at making inferences than their counterparts in the urban public school. Finally, the tests showed that both the urban and rural private school pupils displayed significantly different abilities with respect to some of the questions dealing with extracting information, making inferences and interpreting information.

\section{Implications of the differences in the pupils' comprehension abilities}

The first important implication of our findings for the pupils' academic success relates to their poor critical thinking skills, particularly among the public school group. Our findings show that the pupils at both public and private schools were generally more adept at extracting information than they were at making inferences and interpreting information, though the situation was more precarious with public school pupils, particularly the urban group. Large percentages of pupils scored 0 for questions 4 and 8 , in which they were to infer from the text why chipmunks had stripes on their back and how Chipmunk's attitude differed from that of other animals respectively. The task required of them for these questions and others similar to them necessarily to think analytically. Making inferences and interpreting information, which are contingent on excellent analytical thinking skills, are lifelong learning skills, and the foundation for acquiring such crucial skills is better laid in early school years. While the private schools need to strengthen their pupils in these skills, the public schools definitely need to build a solid foundation for analytical thinking among their students for them to respond appropriately to the rigours of academics beyond the primary school level. Arua et al.'s (2005) finding that few students in public schools had the requisite productive and receptive skills in their first year of junior secondary school, as well as the much better results of the English medium schools in the primary school leaving, junior secondary school and senior secondary school examinations alluded to at the beginning of this paper, support our findings and strengthen our stance with respect to inculcating in the public school pupils a strong foundation for critical analytical thinking.

The second implication is the apparent lack of motivation among the public school pupils. Although we did not empirically measure the learners' motivation, our classroom observation revealed that the pupils in the urban public school were quite unsettled and rowdy. Furthermore, their disposition showed that they were not enthusiastic but rather disinterested. Their disposition of apathy seems to suggest that they would rather not read. While there may have been other allied reasons for their poor performance, their unease was definitely connected to lack of motivation and interest. As noted, standard 4 is an important learning transition point for pupils who are expected to have learnt to read and who should begin to deploy reading for their academic success. We also noted in our discussion the relationship between academic performance and self-perception. Sweet et al. (cited in August et al., 2006) identify lack of motivation or interest in reading as one of the reasons for poor performance in reading comprehension. Similarly, Henk and Melnick (1992), Körük (2017), and Chen (2017) indicate that lack of motivation is linked to how individuals perceive themselves academically. Chapman et al. (2002) also affirm that academic self-perception develops in children based on their competence in important academic skills and how easy they find academic tasks. Arua and Lederer (2003) note that high school students generally lack motivation, which indicates that lack of motivation is prevalent among learners. In fact, our findings confirm that the prevalent lack of motivation to read among learners has its roots in primary school. 
Addressing this issue of motivating pupils to read is extremely important, and stemming the tide of lack of motivation in primary and secondary public schools demands serious scholarly investigation. Such a study should also aim to underscore what the private schools do to motivate their students to read. As Dornyei (2001) notes, even people with exceptional abilities require motivation in order to achieve long-term goals, and the task of motivating adolescents poses one of the greatest challenges to teachers. Two of Dornyei's (2001) suggestions to combat lack of motivation are particularly relevant: providing a learning environment that is both conducive and helpful, and ensuring that norms regarding appropriate conduct are established and agreed to between the teachers and their pupils. Our findings with respect to the seemingly differential abilities of the pupils in the urban and rural public schools on the one hand, and the significant difference between the public and private school pupils on the other, point to the fact that Dornyei's (2001) suggestions are pertinent. The learning environment in the two private schools, for example, was obviously favourable and classes were orderly, hence the learners were very motivated. Between the two public schools, the learning environment in the rural school was definitely more conducive and the classes were more orderly compared with the disruptive environment we witnessed in the urban public school, hence the rural group was more motivated than the urban group. As Snow and Matthews (2016) observe, the role of the classroom environment in which students are immersed is paramount to students' success in learning. We recommend that the learning environment in the public schools should be upgraded as a matter of urgency.

The third implication of our findings relates to class size. As part of our findings, we reported that the pupils in the rural private school were more adept at making inferences and interpreting information, as evidenced by their higher score in explaining how Chipmunk won the argument with Bear. The average class sizes for the rural and urban private schools were 23 and 32 respectively, while those of the rural and urban public schools were 30 and 32 respectively. Class size impinges significantly on how much learning can take place. The amount of learning that can take place is further influenced by, among other factors, the variety of activities that a teacher can carry out with the pupils, how much individual attention the teacher is able to give, maintaining discipline and controlling disruptive behaviour, as well as motivating and sustaining pupils' interest in reading. Although there are different views on what constitutes an ideal class size, it is more likely that a teacher with a class size of 20 will be able to interact more closely with the pupils, vary his or her reading activities, assign more reading tasks, provide feedback speedily, and maintain a more conducive atmosphere for learning than one who has 32 pupils in the class. For example, as part of our findings, we reported that the rural private school pupils were more adept at one of the questions on interpreting information. Chung's (2009) finding that the effect of class size reduction on student achievement was larger in elementary schools than in secondary schools is pertinent in this respect. The job of the teachers in the public schools to provide their pupils with the requisite resources for the development of sound reasoning and analytical skills will definitely be eased if class sizes are maintained at very reasonable levels. It is therefore desirable for class sizes to be maintained at 25 in consonance with the stipulation of the Revised National Policy on Education (1994). 


\section{CONCLUSION}

In this paper, we addressed two questions: Are there significant differences between the comprehension abilities of (a) public and private school pupils, (b) rural and urban private school pupils, and (c) urban and rural public school pupils? What are the implications of the differential abilities for the pupils' academic success? Data for the study were obtained from a comprehension test administered to 378 pupils from two public and two private schools in urban and rural settings in Botswana. The pupils' mean scores in the comprehension test indicated that the private school pupils performed better than their public school counterparts. T-tests of significance applied to the results confirmed that there was a significant difference in the comprehension abilities of the pupils in the urban and rural private schools. The tests also confirmed that, while the urban private school pupils were better at extracting information and making inferences, their counterparts in the rural private school were better at the interpretation of information. While the pupils in the urban and rural public schools displayed no significant differences in their abilities to extract information, the rural public school pupils performed much better than their urban counterparts in making inferences and interpreting information.

In terms of the implications of the findings of our study for the pupils' academic success, we have raised three important areas which demand urgent attention in order to see pupils in the public schools raise their reading comprehension abilities. First, there is the need to motivate the pupils to read by enhancing their learning environment. Second, building a strong foundation for critical/analytical reasoning in the pupils in the public schools is imperative to prepare them to respond appropriately to the demands of academic work beyond the primary school level. Third, maintaining class size at a reasonable level is necessary to motivate learners and develop in them sound reasoning abilities.

\section{END NOTES}

${ }^{1}$ Standard 4 is equivalent to grade 4 or elementary 4 . The term 'standard' is used in this study since it is the nomenclature used in Botswana.

${ }^{2}$ Setswana is the name of the language, while other entities named after the language tend to be referred to as Tswana, e.g., Tswana culture and Tswana medium schools.

${ }^{3}$ The Revised National Policy on Education (1994) stipulates that pupils in public schools are taught in Setswana (the national language) from standard 1-2; and from standard 3 onwards, they transition to English. In private schools, however, English is the language of instruction from the first day in school.

${ }^{4}$ Gaborone is the capital city of Botswana, while Thamaga is a village located about $50 \mathrm{~km}$ to the west of Gaborone.

\section{REFERENCES}

ADEYEMI, SB. 2014. Comparative study of pupils' academic performance between private and public primary schools. World Journal of Education, 4(4):55-60.

ADAMS, MJ. 1990. Beginning to read: thinking and learning about print. Cambridge, MA: MIT Press.

ARNOLD, ML, JH NEWMAN, BB GADDY \& CB DEAN. 2005. A look at the condition of rural education research: setting a direction for future research. Journal of Research in Rural Education, 20(6):1-25. 
ARUA, AE \& M LEDERER. 2003. What are students in Botswana's high schools reading? In AE Arua (Ed.), Reading for all in Africa: building communities where literacy thrives. Newark, NJ: International Reading Association. 26-29.

ARUA, AE, P MOANAKWENA, T ROGERS, TIERNEY, RJ, \& K LENTER. 2005. Improving the quality of literacy learning in the content areas: Situational analysis of secondary level education in Botswana. France: International Reading Association.

AUGUST, D, DJ FRANCIS, H HSU \& CE SNOW. 2006. Assessing reading in bilinguals. The Elementary School Journal, 107(2):221-238. DOI: https://doi.org/10.1086/510656

BLOCK, C, C GAMBRELL \& M PRESSLEY (Eds). 2002. Improving comprehension instruction. San Francisco, CA: Josey Bass.

BORKOWSKI, JG, M CARR, E RELLINGER \& M PRESSLEY. 1990. Self-regulated cognition: interdependence of metacognition, attributions, and self-esteem. In BF Jones \& L Idol (Eds), Dimensions of thinking and instruction. Hillsdale, NJ: Erlbaum. 53-92.

BOTSWANA EXAMINATIONS COUNCIL REPORT. 2014. Progress in International Reading Literacy (PIRLS). Gaborone: Botswana Examinations Council.

BRAUN, H, F JENKINS \& W GRIGG. 2006. Comparing private schools and public schools using hierarchical linear modelling (NCES 2006-461). Washington DC: US Government Printing Office, US Department of Education, National Centre for Education Statistics, Institute of Education Science.

CHAPMAN, JW \& WE TUNMER. 1997. A longitudinal study of beginning reading achievement and reading self-concept. British Journal of Educational Psychology, 67:279-291.

CHAPMAN, JW, WE TUNMER \& JE PROCHNOW. 2002. Early reading skills and performance, reading self-concept, and the development of academic self-concept: a longitudinal study. Journal of Educational Psychology, 92(4):703-708.

CHEN, I. 2017. Kids' self-perception influences academic achievement. Available from https://www.jhunewsletter.com>2017/10/26/ [Accessed: 3 June 2019].

CHEN, JA \& MS TUTWILER. 2017. Implicit theories of ability and self efficacy: testing alternative social cognitive models to science motivation. Zeitschrift Psychol, 225:127-136. DOI: https://doi.org/10.1027/2151-2604/a000289

CARTWRIGHT, F \& MK ALLEN. 2002. Understanding the rural/urban reading gap. Ottawa: Minister responsible for Statistics.

DECHANT, E. 1981. Diagnosis and remediation of reading disabilities. New Jersey: Prentice-Hall.

DEWEY, J. 1910. Science as subject-matter and as method. Science, 31:121-127.

DEWEY, J. 1916. Method in science teaching. The Science Quarterly, 1:3-9.

DEWEY, J. 1938. Experience and education. New York: Collier.

DORNYEI, Z. 2001. Motivational strategies in the classroom. Cambridge: Cambridge University Press.

GOUGH, PB \& WE TUNMER. 1986. Decoding, reading, and reading disability. Remedial and Special Education, 7(1):6-10.

GOVERNMENT OF BOTSWANA. 1994. Revised National Policy on Education. Gaborone: Government Printers.

HAMMERBERG, D. 2004. Comprehension instruction for socio-culturally diverse classrooms: a review of what we know. The Reading Teacher, 57:648-658.

HANNON, B \& M. DANEMAN. 2001. A new tool for understanding individual differences in the component processes of reading comprehension. Journal of Educational Psychology, 93(1):103-128.

HELMKE, A \& MAG VAN AKEN. 1995. The causal ordering of academic achievement and selfconcept of ability during elementary school: A longitudinal study. Journal of Educational Psychology 87:624-637.

HENK, WA \& SA MELNICK. 1992. The initial development of a scale to measure perception of self as reader. In CK Kinzer \& DJ Leu (Eds), Literacy research, theory, and practice: views from many perspectives. Chicago, IL: National Reading Conference. 111-117.

HERBERS, JE, JJ CUTULI, LM SUPKOFF, D HEISTAD, C CHAN, E HINZ \& AN MASTEN. 2012. Early reading skills and academic achievement trajectories of students facing poverty, 
homelessness, and high residential mobility. Educational Researcher, 41(9):366-374. DOI: https://doi.org/10.3102/0013189X12445320

HOOVER, WA \& PB GOUGH. 1990. The simple view of reading. Reading and Writing, 2:127-160.

KEENAN, JM, RS BETJEMANN, K RICHARD \& RK OLSON. 2008. Reading comprehension tests vary in the skills they assess: differential dependence on decoding and oral comprehension. Scientific Studies of Reading, 12(3):281-300. DOI: https://doi.org/10.1080/10888430802132279

KEENE, EO \& S ZIMMERMAN. 1997. Mosaic of thought: teaching comprehension in a reader's workshop. Portsmouth, NH: Heinemann.

KIEFFER, MJ \& NK LESAUX. 2012. Direct and indirect roles of morphological awareness in the English reading comprehension of native Spanish, Filipino, Vietnamese, and English speakers. Language Learning, 62:1170-1204.

KIEFFER, MJ \& NK LESAUX. 2010. Morphing into adolescents: active word learning for English language learners and their classmates in middle school. Journal of Adolescent and Adult Literacy, 54:47-56.

KIEFFER, MJ \& NK LESAUX. 2007. Breaking words down to build meaning: vocabulary, morphology, and reading comprehension in the urban classroom. The Reading Teacher, 61:134-144.

KÖRÜK S. (2017). The effect of self-esteem on student achievement. In E Karadag (Ed.), The factors effecting student achievement. Cham: Springer. 247-257.

LUBIENSKI, C \& ST LUBIENSKI. 2006. Charter, private, public schools and academic achievement: New evidence from NAEP Mathematics data. Occasional Paper, A12.

MULLIS, VS, MO MARTIN, AM KENNEDY, KL TRONG \& M SAINSBURY. 2011. Progress in International Reading Literacy (PIRLS). Amsterdam: International Association for the Evaluation of Educational Achievement (IEA).

NEL, C. 2011. Classroom assessment of reading comprehension: how are preservice foundation phase teachers being prepared? Per Linguam, 27(2):41-66.

OCHENJE, C. 2015. Comparison of standard four pupils' academic performance in public and private primary schools after three years of free primary education (FPE) implementation. International Journal of Education Learning and Development, 3(3):99-108.

ORHAN-ÖZEN, S. 2017. The effect of motivation on student achievement. In E Karadağ (Ed.), The factors effecting student achievement. Eskisehir, Turkey: Springer. 35-56.

PEARSON-LONGMAN TESTS. No date. How the chipmunk got its stripes. Available at http://www.pearsonlongman.com/ae/marketing/sfesl/ tests/ grade4.html\#question1 [Accessed: 31 January 2016].

PETERSON, PE \& E LLAUDET. 2006. On the public-private school achievement debate. Paper prepared for the annual meetings of the American Political Science Association, August 2006, Philadelphia, PA.

POTTS, GR \& SB PETERSON. 1985. Incorporation versus compartmentalization in memory for discourse. Journal of Memory and Language, 24:107-118.

PRESSLEY, M. 2000. What should comprehension be the instruction of? In P Kamil, P Mosenthal, PD Pearson \& R Barr (Eds), Handbook of reading research (Vol. 3). Mahwah, NJ: Erlbaum. 545-561.

SCHUNK, DH. 1991. Self-efficacy and achievement motivation. Educational Psychologist, 26:207231.

SERAFINI, F. 2012. Rethinking reading comprehension. Available from www.frankserafini.com/publications/serafini-rethink-comp.pdf [Accessed: 31 January 2016].

SHIN, I-S \& JY CHUNG. (2009). Class size and student achievement in the United States: a metaanalysis. KEDI Journal of Educational Policy, 6:3-19.

SKAALVIK, EM \& HAGTVET, KA. 1990. Academic achievement and self-concept: an analysis of causal predominance in a developmental perspective. Journal of Personality and Social Psychology, 77:217- 230.

SNOW, C \& TJ MATTHEWS. 2016. Reading and language in the early grades. The Future of Children, 26(2):74.

Per Linguam 2019 35(2):18-38

http://dx.doi.org/10.5785/35-2-800 
SNOW, C. 2002. Reading for understanding: toward a research and development program in reading comprehension. Santa Monica, CA: RAND.

SUKOR, R, AF MOHD AYUB, Z NORHASHIDA, \& AR NOR KHAIZURA. 2017. Influence of students motivation on academic performance among non-food science students taking food science course. International Journal of Academic Research in Progressive Education and Development, 6(4):104-112. DOI: https://doi.org/10.6007/IJARPED/v6-i4/3528

SWEET, AP, JT GUTHRIE \& MM NG. 1998. Teacher perceptions and student motivation: the component processes of reading comprehension. Journal of Educational Psychology, 93(1):103-128.

TAYLOR, N, D GREENBERG, J LAURES-GORE \& J WISE. 2011. Exploring the syntactic skills of struggling adult readers. Reading and Writing, 25(6):1-18.

TRACEY, DH \& LM MORROW. 2006. Reading: An introduction to theories and models. New York: Guilford.

UCCELLI, P, E PHILLIPS GALLOWAY, CD BARR, A MENESES \& CL DOBBS. 2015. Beyond vocabulary: exploring cross-disciplinary academic-language proficiency and its association with reading comprehension. Reading Research Quarterly, 50(3): 337-356. DOI: https://doi.org/10.1002/rrq.104

VAN VECHTEN, D. 2013. Impact of home literacy environments on students from low socioeconomic status backgrounds. In Education Masters. Paper 248. Rochester, NY: St. John Fischer University, Fisher Digital Publications. Available at http://fisherpub.sjfc.edu/education_ETD_masters/248/[Accessed: 4 April 2019].

VELLUTINO, FR. 1979. Dyslexia: theory and research. Cambridge, MA: MIT Press.

VELLUTINO, F R. 1987. Dyslexia. Scientific American, March:34-41.

WOOLFOLK, A. \& K MARGETTS. 2013. Educational psychology (3rd ed.). Australia: Pearson Australia.

\section{BIOGRAPHICAL NOTES}

Prof. Rose Letsholo-Tafila is an Associate Professor of Linguistics at the University of Botswana. She holds a Ph.D from the University of Michigan (Ann Arbor) in Linguistics (Syntax). Her research is mainly on the syntax of Ikalanga Setswana, Khoesan languages, all spoken in Botswana. She also researches on psycholinguistic issues. tafilar@ub.ac.bw

Prof. Modupe Alimi taught English Linguistics and Applied Linguistics at the University of Botswana for many years. Her research interests are in English as a Second Language, English for Academic/Specific Purposes and Second Language Acquisition. malimi@liberty.edu 